\title{
光合成光化学系 II における水分解・酸素発生の反応メカニズム Mechanism of Light-Induced Water-Oxidation/Oxygen Evolution Catalyzed by Photosystem II in Photosynthesis
}

\author{
岡山大学異分野基礎科学研究所 沈 建仁 \\ Research Institute for Interdisciplinary Science, Okayama University \\ Jian-Ren Shen \\ Received September 28, 2018; E-mail: shen@cc.okayama-u.ac.jp
}

\begin{abstract}
Photosystem II (PSII) is a huge membrane-protein complex catalyzing light-induced electron transfer and water oxidation reactions, leading to the conversion of light energy into chemical energy and the evolution of molecular oxygen, two products indispensable for sustaining almost all life forms on the earth. This account describes the structure of PSII with the focus on that of the catalytic center for water oxidation, a $\mathrm{Mn}_{4} \mathrm{CaO}_{5}$-cluster embedded in the protein matrix of PSII, revealed by conventional highresolution X-ray crystallography and femtosecond X-ray free electron laser (XFEL) crystallography. Latest results on the structural changes of the $\mathrm{Mn}_{4} \mathrm{CaO}_{5}$-cluster during the water oxidation reaction cycle obtained by the femtosecond XFEL crystallography are also described. Based on these results as well as those obtained with other approaches, the mechanism of water oxidation and oxygen evolution is discussed. Other functions of PSII such as proton release pathways and light energy absorption and transfer are also discussed briefly.
\end{abstract}

\section{1. はじめに}

各種藻類や植物が行う光合成は、太陽の光エネルギー を利用して水と二酸化炭素から有機物を合成し、同時に 酸素を放出する過程である。これによって作られる有機 物は、他の様々な生物の生存に必要なエネルギーを供給 し、また、分子状酸素は、誕生直後およびその後 15 億 年以上にわたって嫌気的であった地球大気を酸化的なも のに変換し、酸素呼吸を行う生物の出現と進化を可能に した。さらに我々が現在利用している化石エネルギーも、 太古の昔光合成生物が作った有機物が蓄積し、腐敗して 変換されたものである。したがって、光合成は地球上の 生命活動や大気環境の維持に極めて重要な役割を持って いる。

光合成は多くの反応ステップを含む複雑な過程であ り、大きく分けて光を必要とする「明反応」と、光を必 要としない「暗反応」がある。「明反応」は主にシアノ バクテリア細胞や真核藻類、植物の葉緑体内にあるチラ コイド膜と呼ばれる生体膜で行われ、膜上に存在する 様々な色素 一タンパク質複合体が光エネルギーの吸収・

連絡先著者名: 沈 建仁 (しんけんじん)

連絡先 : 700-8530 岡山市北区津島中 3-1-1

岡山大学異分野基礎科学研究所

Tel: 086-251-8502; Fax: 086-251-8502

Corresponding Author: Jian-Ren Shen

Address: Tsushima-naka 3-1-1, Kita-ku, Okayama 700-8530, Japan

Keywords: photosystem II, water oxidation, oxygen-evolving complex,

photosynthesis, Mn cluster, distorted chair, O-O bond formation, X-ray crystallography, X-ray free electron laser, pump-probe experiment.
伝達を行い、それによって一連の電子伝達反応が誘導さ れ、ATP 合成反応が行われるようになる。暗反応は、電 子伝達・ATP 合成反応によってもたらされた高エネル ギー化合物 ATP や還元力を利用して、シアノバクテリ アの細胞質内あるいは真核生物の葉緑体のストロマで、 一連の酵素によって二酸化炭素を糖に変換するものであ る。本稿では、主に明反応のうち、光化学系 II 複合体 (Photosystem II, PSII) ${ }^{1-3)}$ による水分解・酸素発生反応 の機構について紹介する。

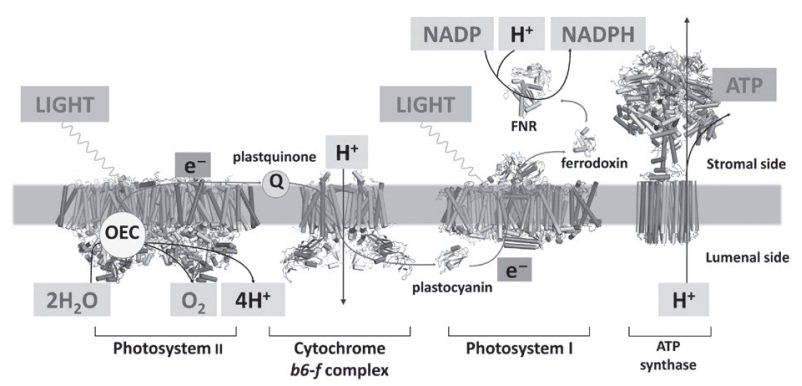

Fig. 1 Membrane protein complexes located in the thylakoid membrane and involved in photosynthetic energy conversion. The shadowed region in the middle represents the membrane region.

Fig. 1 にチラコイド膜の模式図を示す。この膜には、 4 つの大きな膜タンパク質複合体が存在しており、それ ぞれ PSII、シトクロム $b_{6} / f$ 複合体 $\left(\operatorname{cyt} b_{\sigma} / f\right)$ 、光化学系 I (PSI)、および ATP 合成酵素である。太陽の光エネルギ 一は、生物によって種類が異なる、PSII およびPSI コア に結合しているアンテナ色素タンパク質によって吸収 
され、それぞれ PSII, PSI の反応中心色素に伝達される。 PSII およびPSI のコアでは、反応中心色素が受け取った 光エネルギーにより励起され、励起電子がそれぞれ近傍 の電子受容体に移動することで、一連の電子伝達反応が 始まることになる。PSII の反応中心は $\mathrm{P}_{680}$ と呼ばれるク ロロフィル $a$ 分子が 4 つ集まったクラスターで、そのう ちの一つ由来の励起電子は最初の電子受容体であるフェ オフィチンに移動し、その後順にタンパク質に結合し たプラストキノンである $\mathrm{Q}_{\mathrm{A}}, \mathrm{Q}_{\mathrm{B}}$ に移動することになる 1-3)。 $\mathrm{Q}_{\mathrm{B}}$ は 2 電子受容体であり、2 電子を受け取った後 プロトン化され、還元型のプラストキノールになり、結 合部位から外れるようになる。還元されたプラストキノ ールは膜の中を移動し、電子を cyt $b_{6} / f$ に渡す。その電 子はさらに水溶性の電子キャリアであるプラストシアニ ンもしくはシトクロム $c_{6}$ を経て PSI に渡され、最終的 にフェリドキシンを経て $\mathrm{NADP}^{+}$を NADPH に還元する のに利用される。

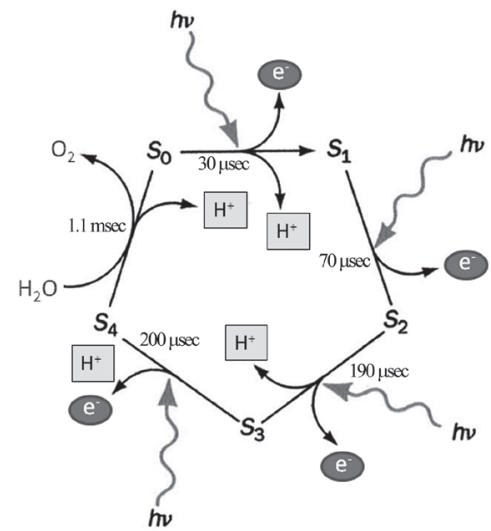

Fig. 2 S-state transition model for the water oxidation reaction catalyzed by the oxygen-evolving complex (OEC) of PSII.

一方、酸化された PSII の反応中心 $\mathrm{P}_{680}$ は近傍のチロシ ン残基から電子を受け取り再還元され、チロシン残基は $\mathrm{Mn}_{4} \mathrm{Ca}$ から構成されるクラスターから電子を奪い取る ${ }^{1-3)}$ 。 $\mathrm{Mn}_{4} \mathrm{Ca}$ クラスターは水分子から電子を奪い取る。そして この電子伝達反応が連続で 4 回行われると、2 分子の水 から 4 電子が奪い取られ、水分子が分解され、一つの分 子状酸素が形成されることになる。したがって、水分解 反応は 4 電子反応であり、この反応の機構を説明するた め、「S- 状態遷移モデル」(Fig. 2) が提唱された ${ }^{4,5)}$ 。この モデルでは、触媒は $\mathrm{S}_{0}-\mathrm{S}_{4}$ の状態を取るとされ、光子が 1 つ吸収されるごとに電子が一つ奪われ、 $\mathrm{S}$ 状態は一つ先 に進むことになる。そして $\mathrm{S}_{3} \rightarrow\left(\mathrm{S}_{4}\right) \rightarrow \mathrm{S}_{0}$ の遷移において分 子状酸素が放出される。これら $\mathrm{S}$ 状態のうち、 $\mathrm{S}_{0}, \mathrm{~S}_{1}, \mathrm{~S}_{2}$, $\mathrm{S}_{3}$ は安定または準安定な状態であり、実験的に捕捉され ているが、 $\mathrm{S}_{4}$ は不安定な状態で、実験的に捕捉されてい ないと言ってよい。この反応モデルは、フラッシュ照射 による酸素発生パターンの測定結果 ${ }^{6)}$ を説明するために
考案されたもので、酸素発生パターンの測定では、暗黒 に適応させておいた試料に短いフラッシュを照射すると、 1, 2 回目の照射では酸素がほとんど観測されないが、3 回 目の照射で酸素発生の大きいピークが観測された。以降 4 回照射ごとに酸素発生のピークが現れ、酸素発生の「4 周期振動」現象が観測されていた。このため、触媒は光 未照射の状態では安定的な $\mathrm{S}_{1}$ 状態にあり、最初の 3 回の フラッシュ照射で $\mathrm{S}_{3} \rightarrow\left(\mathrm{S}_{4}\right) \rightarrow \mathrm{S}_{0}$ の遷移が誘発され、酸素 が発生するが、以降 4 回照射ごとに酸素が発生すること になる。この $\mathrm{S}$ 状態遷移モデルが提案されてから 50 年近 くなるが、その後の様々な手法を用いた実験で、モデル が正しいことが証明されている ${ }^{1)}$

PSII の水分解反応はチラコイド膜のルーメン側で行わ れ、それによって放出される水素イオンはルーメン側で 蓄積することになる（Fig. 1)。また、cyt $b_{\sigma} / f て ゙$ 。行われる 電子伝達・プロトン輸送反応によって、ストロマ側から ルーメン側に水素イオンが輸送され、蓄積されることに なる。このようにルーメン側で蓄積した水素イオンは膜 の両側で水素イオン濃度勾配を形成し、同じチラコイド 膜上に存在する ATP 合成酵素はこの水素イオン濃度勾 配を利用して、ストロマ側でADP とリン酸から ATP を 合成する。合成された ATP と電子伝達によって作られ た NADPH は、二酸化炭素を糖に変換するのに必要な工 ネルギーと還元力を供給する。したがって、光合成の電 子伝達によって光エネルギーは生物が利用可能な化学工 ネルギーに変換されることになる。

\section{2. 光化学系 II の全体構造}

PSII は多くのサブユニットから構成される巨大膜夕 ンパク質複合体で、そのうち、表在性サブュニットや 低分子量膜貫通サブユニットのいくつかは生物種によ

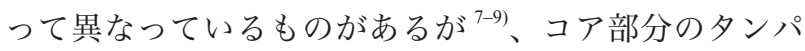
ク質組成は原核のシアノバクテリアから真核の高等植 物まで高度に保存されている ${ }^{1-3)}$ 。PSII の構造を原子レ ベルで解明するため、筆者らは安定性が高く、取り扱い が容易な、温泉から採取した高熱性シアノバクテリア Thermosynechococcus vulcanus から PSII 二量体を調製し 10,11)、結晶化を行つた ${ }^{12)}$ 。得られた結晶の分解能は当初 十分ではなかったが ${ }^{13)}$ 、様々な結晶化条件・結晶の凍結 条件を最適化した結果、結晶の質を大幅に向上させるこ とができ、SPring-8 の放射光 X 線を利用して回折デー夕 を収集し、構造解析を行った結果、1.9 ^分解能で PSII の構造を解析することができた ${ }^{14)}$ 

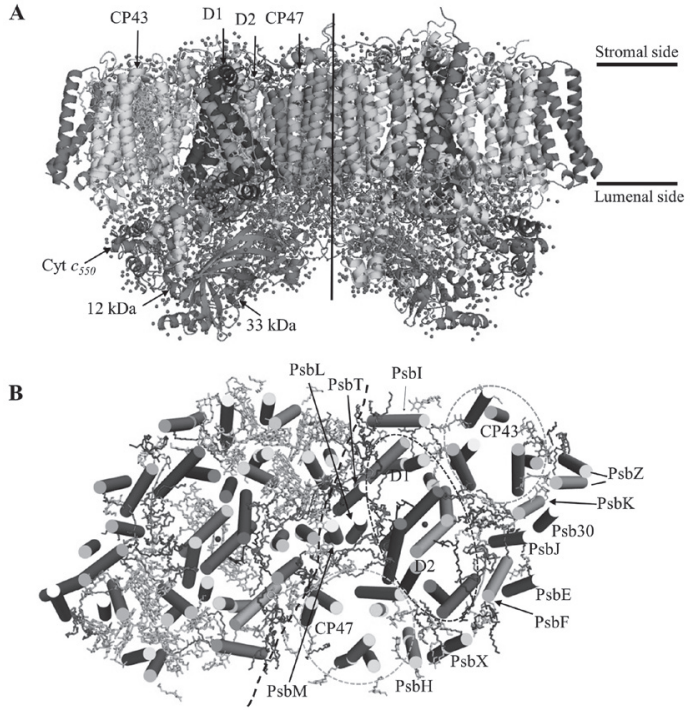

Fig. 3 Crystal structure of a PSII dimer. A. Side view; B. Top view from the stromal side. Solid line in the middle of panel $A$ and dashed line in the middle of panel $B$ divide two monomers.

PSII は二量体として存在し、その全体構造を Fig. 3A に示した。この図では、真ん中に 2 回回転対称軸があり、 2つの PSII 単量体を左側と右側に分けている。また、上 側がストロマ側で、下側がルーメン側を示している。

PSII の中心部分は 4つの大きな膜貫通サブユニット、 D1，D2，CP47，CP43 が占めており（Fig. 3B)、そのうち、 D1, D2 はそれぞれ 5 回ずつ膜を貫通し、PSII のすべて の電子伝達成分を結合している。CP47, CP43 はそれぞ れ 6 回ずつ膜を貫通し、多数のクロロフィル $a$ を結合し ており、反応中心に光エネルギーを直接渡す光捕集アン テナの役割を果たしている。この 4 つの大きな膜貫通サ ブユニットの周りには、13 個の小さい（低分子量、分 子質量が $10 \mathrm{kDa}$ 以下の）膜貫通サブユニットが取り囲 んでおり、複合体の構造維持や安定化などの役割を果た している。これらの低分子量サブユニットのうち、PsbZ は2 回膜貫通ヘリックスを持っているが、その他のサブ ユニットはいずれも 1 回膜貫通ヘリックスのみを持って いる (Fig. 3B) 2,3)。

PSII のルーメン側表面には 3 つの水溶性サブユニッ 卜、PsbO, PSbU, PsbV が結合して抢り、水分解の触媒中 心である $\mathrm{Mn}_{4} \mathrm{Ca}$ クラスターのフ夕の役割を担っており、 当該クラスターを水溶液から隔離し、安定化する働きを 持っている $2,3,7-9) 。$

タンパク質を取り除いた、電子伝達成分の配置を示し たのが Fig. 4 で、各電子伝達成分間の距離・分子の配向 関係が示されている。これら分子間の距離・配向は長い 進化の結果、電子伝達反応が最適化され、逆反応が極力 抑えられるようになったと考えられる。

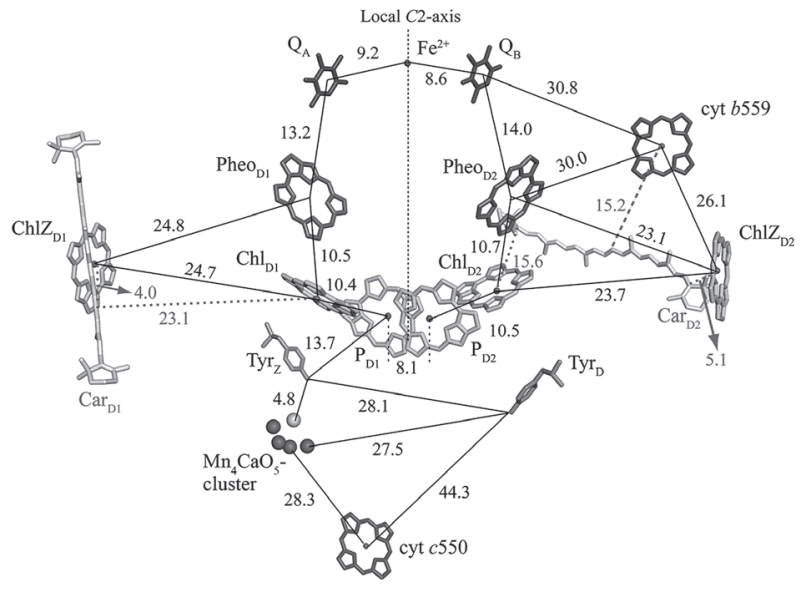

Fig. 4 Arrangement of the electron transfer cofactors in PSII. Numbers are distances depicted in $\AA$.

上述したように PSII の反応中心は $\mathrm{P}_{680}$ と呼ばれる $4 つ$ のクロロフィルからなっているが、最初に光を吸収する クロロフィルは、D1 タンパク質に結合している、光合成 細菌の反応中心との類似性から「アクセサリークロロフ イル」と呼ばれる、Chl $\mathrm{D}_{\mathrm{D} 1}$ であると考えられている ${ }^{15,16}$ 。 励起された $\mathrm{Ch}_{\mathrm{D} 1}$ は極めて短い時間で $\mathrm{P}_{\mathrm{D} 1}$ から電子を受け 取り、再酸化される。 $\mathrm{P}_{\mathrm{D} 1}$ は $\mathrm{D} 2$ サブユニットに結合して いるもう一つのクロロフィル、 $\mathrm{P}_{\mathrm{D} 2}$ と相互作用し、二量体 を作っており、正のホールは $\mathrm{P}_{\mathrm{D} 1} / \mathrm{P}_{\mathrm{D} 2}$ に一部非局在化して いるが、 $\mathrm{P}_{\mathrm{D} 1}$ により多く局在化していることが理論計算 によって示されている ${ }^{17,18)}$ 。Chl $\mathrm{Ch}_{1}$ は極めて短寿命である が、酸化された $\mathrm{P}_{\mathrm{D} 1} / \mathrm{P}_{\mathrm{D} 2}$ はある程度の寿命を持って存在す るので、PSII の “安定的” な反応中心 $\mathrm{P}_{680}$ は一般的にこ の $\mathrm{P}_{\mathrm{D} 1} / \mathrm{P}_{\mathrm{D} 2}$ 二量体を指す。

光によって励起された $\mathrm{P}_{680}$ 由来の電子は、フェオフィ チン、D2, D1 サブユニットに結合している $\mathrm{Q}_{\mathrm{A}}, \mathrm{Q}_{\mathrm{B}}$ の順 に伝達し、cyt $b_{6} f f$ 経由してPSI に送られることになる。 また、PSII の酸化側では、 $\mathrm{P}_{680}$ の近傍に存在する、D1 サブユニットのチロシン残基 $\mathrm{Tyr} 161$ が $\mathrm{P}_{680}$ に直接電子 を供給し（Fig. 4)、そして Tyr161 はその近傍に存在し ている $\mathrm{Mn}_{4} \mathrm{CaO}_{5}$ クラスターから電子を受け取り、再酸 化さ机、 $\mathrm{Mn}_{4} \mathrm{CaO}_{5}$ クラスターは水分子から電子を奪い 取ることになる。一連の電子伝達反応は $\mu \mathrm{sec}-\mathrm{msec} の$ 時間スケールで完了する。

\section{3. $\mathrm{Mn}_{4} \mathrm{CaO}_{5}$ クラスターの構造と水分解反応の機構}

3.1. 放射光によって解析された $\mathrm{Mn}_{4} \mathrm{CaO}_{5}$ クラスター の高分解能構造

上述のようにPSII における水分解の直接の触媒は $\mathrm{Mn}_{4} \mathrm{CaO}_{5}$ クラスターであるが、このクラスターの正確 な化学組成と構造は長い期間不明であった。PSII の結晶 構造は 2001 年にドイッの Zouni らによって初めて報告 
され、そのときの分解能は $3.8 \AA$ であつた ${ }^{19)}$ 。その後著 者らを含む 3 つの゙ループにより分解能は徐々に向上さ れ、2009 年までに $2.9 \AA$ までにあがつた ${ }^{13,20-23)}$ 。しかし、 後述のように $\mathrm{Mn}_{4} \mathrm{CaO}_{5}$ クラスター中の $\mathrm{Mn}$ 一 $\mathrm{O}$ 原子間の 距離が 1.8-2.0 A 前後であるので (Fig. 5)、クラスター 中の原子の位置を電子密度から明確に判別できるために は、原理的には同程度の分解能が必要である。したがっ て、2.9 ^分解能までの構造では、クラスター中の $\mathrm{Mn}$, Ca のような重い原子（金属イオン）の数やおおよその 位置は分かるが、その間をつないでいるオキソ酸素の数・ 位置はあいまいで、全体の構造を決定するには至らなか つた。

筆者らが 2011 年に発表 した $1.9 \AA$ 分解能の PSII 構造において ${ }^{14)}$ 、オキソ 酸素を含めた $\mathrm{Mn}_{4} \mathrm{CaO}_{5}$ ク ラスター中の各原子の位 置が初めて電子密度に基 づき決定され、クラス夕 一の全体構造が明らかに なった（Fig. 5A)。この 構造では、3つの Mn イ オンと1つの $\mathrm{Ca}$ イオン が 4 つオキソ酸素によ つてつながれ、キュバン 型構造を作っており、そ の外側に 4 つ目の Mn イ オン Mn4 が2つのオキソ 酸素を通してキュバン部 とつながり、全体が「ゆ がんだイス」のような形 になっている (Fig. 5B)。 4つの Mn イオンのうち、 キュバンの外側にある $\mathrm{Mn} 4$ には2つの水分子が、 また、Caイオンにも $2 つ$ の水分子が末端配位子と して結合している。その ほかの配位子は合計 7 つ のアミノ酸によって供給

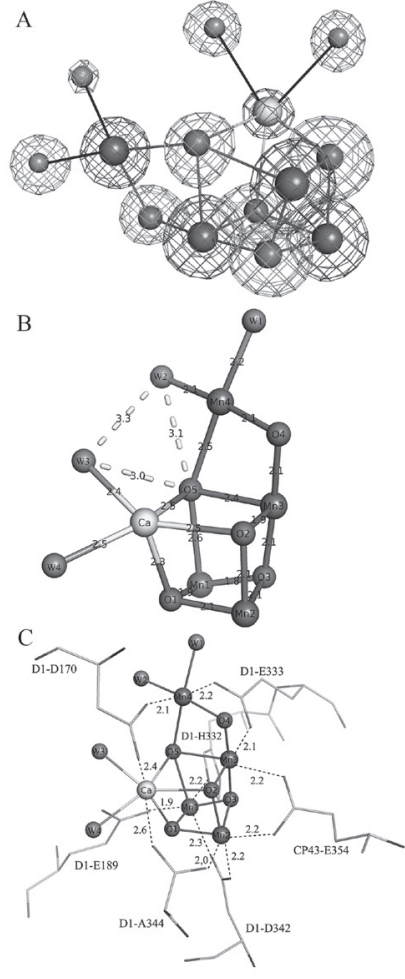

Fig. 5 Structure of the $\mathrm{Mn}_{4} \mathrm{CaO}_{5}-$ cluster determined at $1.9 \AA$ resolution by SPring-8 synchrotron X-rays. A. Superposition of the atoms with their omit electron density maps; B. Distorted chair form of the $\mathrm{Mn}_{4} \mathrm{CaO}_{5}$-cluster with their inter-atomic distances depicted in $\AA$; C. Coordination structure of the $\mathrm{Mn}_{4} \mathrm{CaO}_{5}$-cluster with their amino acid ligands.
され (Fig. 5C)、そのうちの6つが D1 サブユニット、1 つのみが CP43 サブユニットから供給されている。これ らの配位アミノ酸のうち、6つがカルボキシル基を供給 し、一つのみがヒスチジン由来のアミド基である。

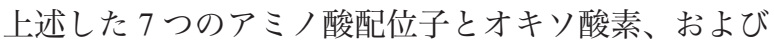
4 つの水配位子によって、 $\mathrm{Mn}_{4} \mathrm{CaO}_{5}$ クラスター中の 4 つ の Mnイオンはそれぞれ 6 配位構造、また、Ca イオン は 7 配位構造を取っていることが分かった（Mn1 と O5
の距離が通常の $\mathrm{Mn}-\mathrm{O}$ 結合距離より著しく長く、そ の間の結合があるかどうかは議論があるところである。 詳細は後述)。また、6つのカルボキシル基を持つアミ ノ酸のうち、5つは2つの金属イオン $(\mathrm{Mn}$ と $\mathrm{Mn}$ 、ま たは $\mathrm{Mn}$ と Ca）に配位する bidentate 構造を取っており、 一つのみ (D1-Glu189)が monodendate 構造となっている。 $\mathrm{Mn}$ 一 Mn イオン間の距離は Mn1-Mn2 で $2.8 \AA 、 \mathrm{Mn} 2$ Mn3 で $2.9 \AA 、 \mathrm{Mn} 3-\mathrm{Mn} 4$ で $3.0 \AA 、 \mathrm{Mn} 1-\mathrm{Mn} 3$ で $3.3 \AA$ 、 Mn1一Mn4 で $5.0 \AA$ 、Mn2—Mn4 で $5.4 \AA$ であった（Fig. 6A）（Mnイオン同士の距離に関する詳細な議論は磯部 による総説を参照) ${ }^{24)}$ 。

A

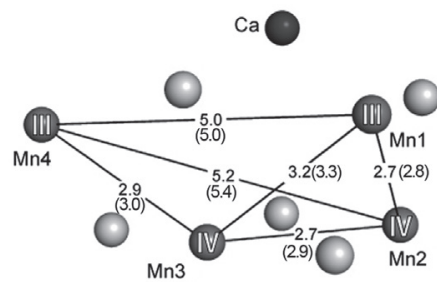

B

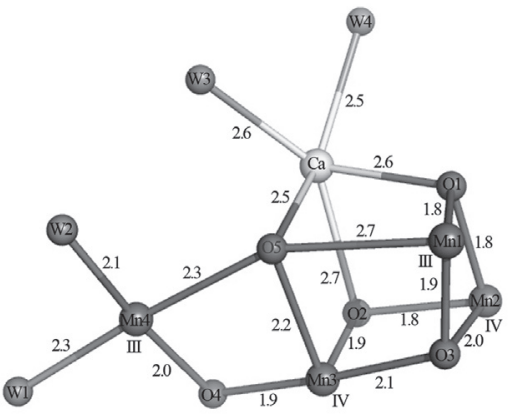

Fig. 6 Inter-atomic distances of the $\mathrm{Mn}_{4} \mathrm{CaO}_{5}$-cluster determined by XFEL. A. Mn-Mn distances (numbers in parenthesis are distances determined by the SPring- 8 synchrotron $\mathrm{X}$-rays); B. Inter-atomic distances within the $\mathrm{Mn}_{4} \mathrm{CaO}_{5}$-cluster.

しかし、X 線結晶構造解析によって決定された $\mathrm{Mn}$ 一 $\mathrm{Mn}$ 同士、特に Mn1-Mn2、Mn2-Mn3、Mn3-Mn4 間の距離は、これまでX線吸収スペクトル（EXAFS, extended X-ray absorption fluorescence spectra）測定によっ て推定された距離よりわずかに（0.1-0.2 凡程度）長か つた ${ }^{25,26)}$ 。また、筆者らが決定した結晶構造の座標を用 いて、理論計算 (量子力学／分子力学、 $Q M / M M$ 計算) によって得た $\mathrm{Mn}$ - $\mathrm{Mn}$ 間距離のいくつかも、結晶構造 よりわずかに短いことが報告された ${ }^{27-32)}$ 。このような、 結晶構造と EXAFS 測定、QM/MM 計算結果間の相違の 原因として、X線による損傷があげられた。2011 年で 決定された $\mathrm{Mn}_{4} \mathrm{CaO}_{5}$ クラスターの構造は、SPring-8の 連続放射光 $X$ 線を利用して解析されたもので、その際、 結晶由来の回折データ 1 枚につき、約 1 秒間 X 線を照 射して得られたものである。完全な回折デー夕を収集す るため、 $180^{\circ}$ にわたって $0.2^{\circ}$ おきに結晶を回転し、回 折イメージを収集したので、大きい結晶を用いてできる 
だけ結晶の異なる部位から回折デー夕を収集する方法を 取ったにもかかわらず、同じ結晶部位に合計数十秒にわ たって強いX線を照射したことになる。その結果、夕 ンパク質のアミノ酸、特に PSII に含まれる Mnイオン はX線損傷を受け、構造が変化した可能性が否定でき なかった。後述のように $\mathrm{Mn}_{4} \mathrm{CaO}_{5}$ クラスター中の $\mathrm{Mn}$ イオンは 3 価もしくは 4 価の状態にあるので、X線損傷

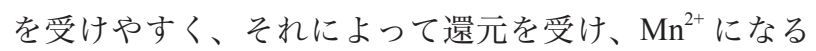
可能性がある。その結果、 $\mathrm{Mn}$ - Mn 同士の距離が長くな る可能性を否定できなかった。

$\mathrm{Mn}_{4} \mathrm{CaO}_{5}$ クラスターの「ゆがみ」を作りだしている 要因は2つある。1つは、キュバン構造のなかに含まれ る4つの金属イオンのうち、3つがMnイオンで、1つ のみが $\mathrm{Ca}$ イオンとなっている。 $\mathrm{Mn}-\mathrm{O}$ 原子間の典型 的な結合距離が $1.8-2.1 \AA$ であるのに対して、 $\mathrm{Ca}-\mathrm{O}$ 原子間の結合距離が $2.4-2.7 \AA$ であるため (Fig. 5B)、 キュバンの中の原子間距離が均一ではない。もう一つの 要因は、5つのオキソ酸素原子のうち、O 1 - O4 までの 4 つの酸素原子と Mn との結合距離が典型的な $1.8-2.1$ A 程度になっているが、O5 と Mn との結合距離が 2.5 $2.6 \AA$ で、著しく長くなっている (Fig. 5B)。このことは、 触媒の構造に歪みをもたらしただけでなく、O5 が特殊 な位置にあり、Mn との結合が弱く、このため、反応中 に結合部位から切り出され、分子状酸素の形成に関わる 可能性があること、すなわち、O5を中心とした部位が 反応部位であることを示唆している。しかし、このよう な原子間距離に基づいた考察も、もし触媒が $\mathrm{X}$ 線損傷 を受け、構造が変化していたなら、成り立たなくなる可 能性がある。

\section{2. $\mathrm{Mn}_{4} \mathrm{CaO}_{5}$ クラスターの無損傷構造と酸化状態}

水分解反応の機構を解明するため、損傷を受けてい ない、天然状態の $\mathrm{Mn}_{4} \mathrm{CaO}_{5}$ クラスターの構造を解析す ることが不可欠である。通常、X線による損傷は、強 いX線の照射により、分子または結晶中の水分子が攻 撃を受け、ラジカルとなる活性酸素種を生じさせ、そ れらがアミノ酸または金属イオンを攻撃し、構造が変 化することによる。この一連のイベントはピコ秒単位 で起こるとされている。したがって、X線損傷をなく すためには、ピコ秒よりも短い時間でX 線回折データ を収集する必要がある。このような極短い時間の X 線 パルスでは、1 パルス当たりの X 線量（光子数）を通 常の放射光 $X$ 線よりも $10^{11}-10^{12}$ 倍もしくはそれ以上 大きくする必要がある。このような極大強度・極短時 間の X 線パルスを供給できるのが、フェムト秒の $\mathrm{X}$ 線 自由電子レーザーXFEL（X-ray Free Electron Laser）で ある ${ }^{33}$ 。XFEL 装置はアメリカのスタンフォードで世界 初の装置 LCLS（Linac Coherent Light Source）が建設さ
れ、2009 年に運用が開始した。その 3 年後の 2012 年春、 世界で 2 番目の XFEL 施設 SACLA（SPring-8 Angstrom Compact Free-electron Laser) が日本で建設・運用開始さ れた ${ }^{34)}$ 。SACLAの XFELは、1 パルスの時間が $10 \mathrm{fsec}$ で、 SPring-8 の X 線と同等または若干低い X 線量を供給し てくれる。このような XFEL パルスを利用することで、 X 線損傷を受けない構造を解析することができるように なる。

$\mathrm{Mn}_{4} \mathrm{CaO}_{5}$ クラスター中の $\mathrm{Mn}$ - $\mathrm{Mn}$ イオン間の距離を 決定し、X 線損傷によって変化したものと区別するため、 分解能の高い構造解析が必要である。しかし、XFELの パルス $\mathrm{X}$ 線の強度が極女て高いため、結晶に 1 パルス XFEL を照射すると、照射された箇所が破壊され、次 の X 線パルス照射ができなくなる（X線回折デー夕は 結晶が破壊される前に得られるので、影響を受けない) 35)。すなわち、結晶の 1 か所あたり 1 回折イメージし か取得できない。通常の X 線結晶構造解析では、結晶 を回転しながら一定の角度ごとに回折データ（イメー ジ）を収集するので、数百枚－1000 枚程度の回折イメ ージを収集する必要がある。したがって、XFELを用い た結晶構造解析では、小さい結晶（ナノメートルーマイ クロメートルサイズ）を用いて、結晶を連続的に交換 しながら XFELを照射するという「シリアルフェムト 秒結晶構造解析法」、(SFX 法、Serial Femtosecond X-ray Crystallography）が考案され、利用されていた ${ }^{36,37)}$ 。 の方法では、微小結晶をジェット気流などと類似の方法 により噴出し、連続的に供給しながら、それに対して一 定周波数の XFEL パルスを照射する。噴出された気流中 での結晶の配向がランダムであるため、X 線に対する結 晶の配向もランダムで未知である。したがって、回折イ メージを取得後、結晶の方位を回折データからシミュレ ーションにより推定するという手法を取る必要があり、 それのためのソフトウェア (CrystFEL など $)^{38)}$ が開発さ れていた。しかし、シミュレーションによる結晶方位の 推定にはある程度の誤差が含まれるため、方位が近い結 晶からの回折データをできるだけ多く収集し、推定の精 度を上げる必要があった。したがって、通常のX 線結 晶構造解析で用いる回折データの圥長度 (Redundancy、 あるいは Multiplicity）が 10 以下で十分であるのに対し て、XFELの回折データの呪長度は通常 100 以上が必要 で、300-800 程度が望ましい。これは、測定に必要な 微小結晶の数が大量に必要であることを意味する。

PSII のような巨大膜タンパク質結晶について、SFX 法の問題点は、PSII の微小結晶では分解能が高くないこ とであった。微小結晶で分解能が大きい結晶より低い原 因は2つ考えられる。一つはPSIIの分子量が大きいため、 微小結晶中に含まれる分子数が少なく、回折に有効な繰 り返しユニット数が少ないこと、もう一つは大きい結 
晶が成長する結晶化条件は結晶形成に最適化されたもの で、得られた結晶について最高の分解能を与えるが、微 小結晶の成長条件は必ずしも結晶の形成と成長に最適で はなく、結晶を大きく成長させないため、「準最適」の 結晶化条件下で結晶するか、結晶が大きくなる前に成長 を止めてしまうといつた措置を取る必要があり、得られ た結晶の質が必ずしも最善のものではない、ということ である。しかし、 $\mathrm{Mn}_{4} \mathrm{CaO}_{5}$ クラスター中の $\mathrm{Mn}-\mathrm{Mn}$ 原 子間の距離を十分な精度で決定し、損傷を受けた構造と の区別をするためには、十分高い分解能の構造解析が必 要である。この問題を解決するため、筆者らはPSII の 大型結晶を用いて、凍結条件で結晶の 1 か所に XFEL を 1 パルス照射し、結晶を $50 \mu \mathrm{m}$ 移動して次の XFEL パル スを照射するという「固定ターゲットシリアル結晶構 造解析法」を用いて回折データを収集した（Fig. 7） ${ }^{39)}$ 。 XFEL のビームサイズは $2-3 \mu \mathrm{m}$ であるので、予備実 験により $50 \mu \mathrm{m}$ 移動すれば、XFEL 照射による影響を受 けていない結晶部位から回折デー夕を収集できることを 確認した ${ }^{40)}$ 。この方法により、大型 PSII 結晶（長さ約 $1 \mathrm{~mm}$ )を利用して、1 結晶当たり数十枚一 100 枚程度 の回折イメージを収集することができた。結晶の中心か ら外れた部位では、分解能が低下したり、回折イメージ のスポットが割れたりといつた問題も生じるので、収集 したすべてのイメージを構造解析に利用することはでき なつた。このため、一つの完全な回折データセットを収 集するため、数十から数百個の大型 PSII 結晶が必要で あつた ${ }^{39)}$ 。

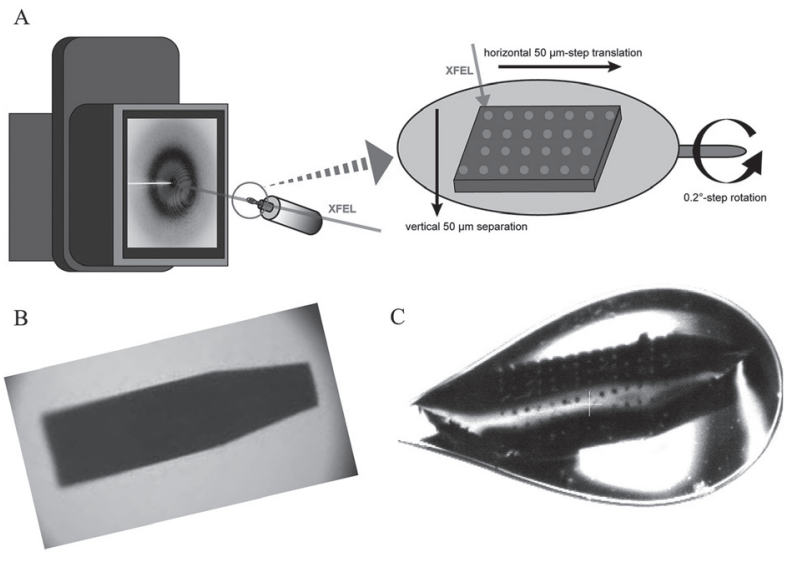

Fig. 7 Fixed-target serial femtosecond X-ray crystallography using XFELs and a large PSII crystals. A. Illustration of the experimental set-up; B. A large PSII crystal (with a length over $1.0 \mathrm{~mm}$ ) before XFEL irradiation; C. The PSII crystal after XFEL irradiation. A lot of bubbles in the surface of the crystal can be seen which are caused by irradiation of a single femtosecond XFEL pulse.

このような「固定ターゲット結晶構造解析法」を用 いて、フェムト秒の XFEL パルスにより $1.95 \AA$ 分解能 の PSII 構造を解析することができた ${ }^{39)}$ 。その結果、Fig. 6A で示したように、Mn1 - Mn2, Mn2 - Mn3, Mn3 -
Mn4 間の距離がそれぞれ $0.1-0.2 \AA$ ずつ短くなり、他 の $\mathrm{Mn}-\mathrm{Mn}$ 原子間の多くも短くなった。これらの距離 は EXAFS 測定や QM/MM 計算結果とほぼ一致してお り、XFELによって解析された構造がX 線損傷を受け ていない、天然状態の構造であることを示した。ただ、 EXAFS 測定で得られたのは原子間距離のみで、クラス 夕ーの幾何学構造は結晶構造解析で初めて明らかになつ たものである。また、 $\mathrm{QM} / \mathrm{MM}$ を用いた理論計算は、一 部タンパク場の環境やカルボキシル基、イミダゾール基、 および水分子のプロトン化状態に依存し、さらに計算に 用いられたパラメーターの值によっても結果が変わる可 能性があり、得られた結果は必ずしも結晶構造解析から 得られた結果と厳密に一致するとは限らない。また、結 晶構造解析では原子間距離に一定の誤差が含まれてお り、これも $\mathrm{QM} / \mathrm{MM}$ 計算や EXAFS 測定の結果との間の ずれの一因になる。

無損傷で解析された $\mathrm{Mn}_{4} \mathrm{CaO}_{5}$ クラスターの構造にお いて、 $\mathrm{Mn}$ - O、および $\mathrm{Mn}$ と配位子間の距離の一部も 放射光 X線で解析された構造から変化していたが（Fig. 6B)、その多くは若干短くなっていた。しかし、O5 と Mn1, Mn4 との距離はそれぞれ $2.7 \AA 、 2.3 \AA$ となり、放 射光 X 線構造からわずかに変化したが、他の典型的な $\mathrm{Mn}$ - $\mathrm{O}$ 間距離より著しく長いという特徵は維持されて おり、O5が他のオキソ酸素に比較して特殊な位置にあ る性質は変わらなかった。この特徵は、極めて低線量の 放射光 X線によって解析された無損傷・高分解能構造 でも観測された ${ }^{41)}$ 。したがって、O5を中心とする部位 が $\mathrm{O}=\mathrm{O}$ 形成に関わる反応部位であることは無損傷構造 でも示唆された。

無損傷構造における Mn と配位子間との距離から、 Mn イオンの酸化状態（価数）を推定することができる。 解析された構造は光未照射のものなので、 $\mathrm{S}_{1}$ 状態に対 応する。電子スピン共鳴 (EPR, electron paramagnetic resonance）やEXAFS などの手法を用いたこれまでの 研究で、 $\mathrm{S}_{1}$ 状態における $\mathrm{Mn}_{4} \mathrm{CaO}_{5}$ クラスター中の 4 つ の Mnイオンの価数状態は一般的に III, III, IV, IV（以 降 3, 3, 4, 4 とする）であることが報告されている (これより 2 電子多い状態、2, 3, 3, 4 という「低酸化状

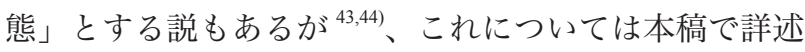
しない)。4つの Mn はいずれも6 配位であり、それぞ れ 2 つ配位子が Mn 原子を中心にほぼ直線で結ばれ て、一つの配位子ペアを作っているが、配位子ペア間で Mn イオンとの平均結合距離に違いがあつた。そのうち、 Mn2, Mn3 に結合している3つの配位子ペアの結合距離 はいずれも $1.8-2.0 \AA$ の範囲内にあり（Fig. 8)、典型 的な $\mathrm{Mn}-\mathrm{O}$ 結合距離と変わらない。しかし、Mn1 と Mn4 の 3 つの配位子ペアのうち、それぞれ一つのペア が Mn との平均結合距離が $2.0 \AA$ より明らかに長く (Mn1 
- O5/Asp342 = $2.46 \AA$, Mn4 - O5/W1 = $2.29 \AA$ )、通常の $\mathrm{Mn}-\mathrm{O}$ 結合と異なる性質を示した。このような長い結 合ペアは 3 価 Mn に特有の Jahn-Teller 軸に対応しており、 したがって、Mn1, Mn4 はそれぞれ 3 価であり、Mn2, Mn4 は 4 価であることが示された ${ }^{39) 。}$

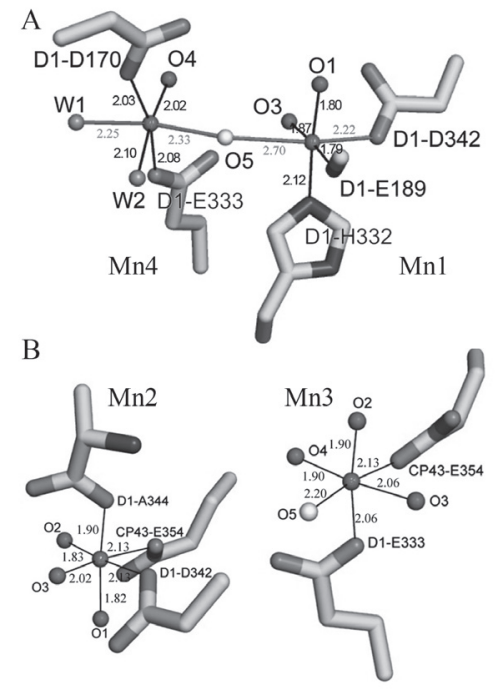

Fig. 8 Ligand distances of the four $\mathrm{Mn}$ ions in the radiation damage-free structure determined by XFEL. A. Mn4 and Mn1; B. $\mathrm{Mn} 2$ and Mn3.

\section{3. $\mathrm{S}_{2}$ 中間体の構造}

以上により決定された $\mathrm{Mn}_{4} \mathrm{CaO}_{5}$ クラスターの構造は、 暗黒で安定な、反応開始前の $\mathrm{S}_{1}$ 状態の構造であり、こ の構造から、O5 を中とする領域が分子状酸素の形成 に関わっている反応部位である可能性が示唆された。し かし、O5 の近傍で Mn4 に配位している水分子W2、お よび Ca に配位している水分子 W3 が存在しており、い ずれも O5 と水素結合距離にある。この領域でどの $2 つ$ の酸素原子が近づき、反応が行われるか、それに伴い $\mathrm{Mn}_{4} \mathrm{CaO}_{5}$ クラスターの構造がどのように変化し、また、 プロトンがどの経路から放出されるかといつた問題に対 する答えは不明である。これらの問題に答えるために は、S 状態遷移の中間状態の構造を解析しなければなら ない。

$\mathrm{S}_{1}$ 状態に 1 フラッシュを照射すると触媒は $\mathrm{S}_{2}$ 状態に 遷移する。 $\mathrm{S}_{2}$ 状態の構造は今のところ実験から報告され ていないが、理論計算 $(\mathrm{QM} / \mathrm{MM}$ 計算) から 2 種類ある ことが報告されている ${ }^{45,46)}$ 。一は、O5が Mn4 に近づき、 強い結合を作り、Mn1 との結合が切れるオープン型キ ユバン構造（あるいは右側オープン、右型構造 ${ }^{45)}$ )、も う一つはその逆で、O5 が Mn1 に近づき、クローズドキ ユバン型構造 (左側オープン、左型構造) である (Fig. 9)。 これまで低温で $\mathrm{S}_{2}$ 状態から 2 つ EPR 信号が観測され ており、それぞれマルチライン信号と $g=4.1$ 信号であ

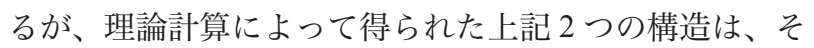

れぞれ EPR のマルチライン信号 (右型) と $g=4.1$ 信号 (左型) に対応するものであることが示唆された。2つ の EPR 信号のうち、マルチライン信号が優位であり、 $g$ $=4.1$ 信号は実験条件によっては観察されないことがわ かっているが、これらに対応する 2 タイプの構造は今の ところ実験では解析されていない。

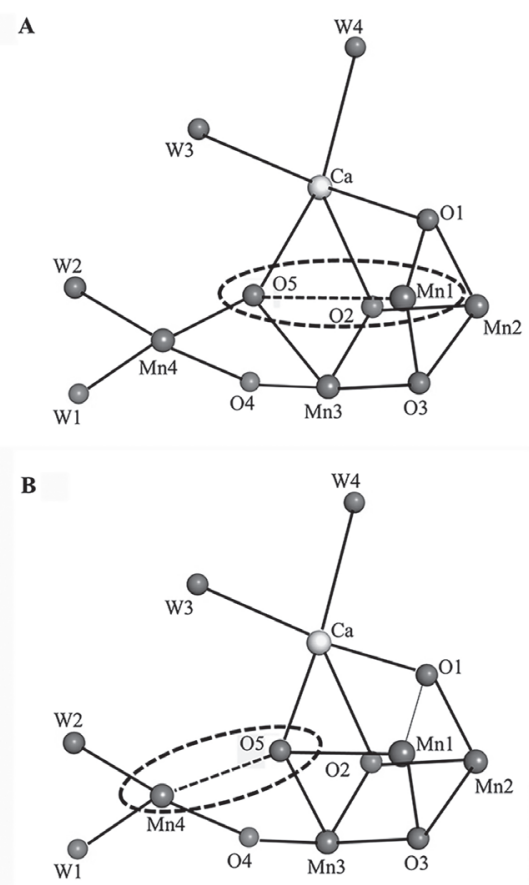

Fig. 9 Two types of structures of the $\mathrm{Mn}_{4} \mathrm{CaO}_{5}$-cluster at the $\mathrm{S}_{2}$ state based on theoretical calculations. A. Open-cubane (right-side open) structure; B. Closed-cubane (left-side open) structure.

\section{4. $\mathrm{S}_{3}$ 中間体の構造}

$\mathrm{S}_{2}$ 状態からさらに 1 フラッシュ照射すると $\mathrm{S}_{3}$ 状態に 遷移する。この時、右型から優先的に遷移するか、左型 から遷移するかなどについて様々な理論計算が行われ ているが ${ }^{47-50)}$ 、筆者らは XFEL と微小結晶を用いた SFX 法を利用したポンプ - プローブ実験により、 $\mathrm{S}_{3}$ 状態由来 の $\mathrm{X}$ 線回折デー夕を収集し、 $\mathrm{S}_{1}$ 状態とのフーリエ差電 子密度から $\mathrm{S}_{1}$ 状態から $\mathrm{S}_{3}$ 状態へ遷移する際の構造変化 を特定し、 $\mathrm{O}=\mathrm{O}$ 結合の形成部位について重要な知見を 得た ${ }^{51)}$ 。

上述のように SFX 法では、多数の微小結晶を用いて 連続的に結晶試料を供給しながら一定間隔でフェムト秒 の XFEL パルスを照射し、回折データを得る。 $\mathrm{S}_{3}$ 状態 由来の回折データを得るため、532 nmのグリーンレー ザーをポンプとし、10 msec の間隔で 2 回照射し、2 回 目の照射後、10 msec 経過した時点でXFELを照射して 回折データを取得した。 $S_{3}$ 状態由来のデータから光未 照射の $\mathrm{S}_{1}$ 状態由来のデータを差し引いたフーリエ差電 子密度図から、 $\mathrm{S}_{1}$ から $\mathrm{S}_{3}$ への遷移によって引き起こさ れた構造変化が明らかになった（Fig. 10）。 


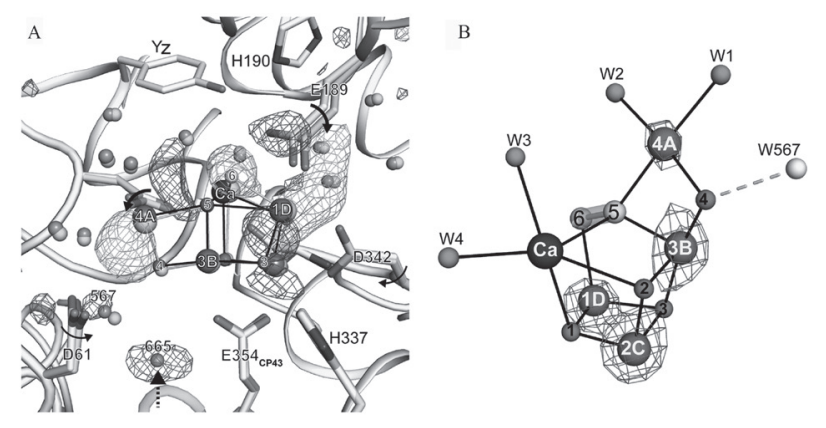

Fig. 10 Structural changes of the $\mathrm{Mn}_{4} \mathrm{CaO}_{5}$-cluster induced by 2-flashes illumination. A. Isomorphous Fourier-difference map of $\mathrm{S}_{3}-\mathrm{S}_{1}$ state around the $\mathrm{Mn}_{4} \mathrm{CaO}_{5}$-cluster; $\mathrm{B}$. Position of the $\mathrm{O} 6$ atom in the $S_{3}$-state based on the $S_{3}-S_{1}$ isomorphous Fourier-difference map.

差フーリエ電子密度から、二次電子供与体 $Y_{D}$, 電子受 容体 $\mathrm{Q}_{\mathrm{B}}$ および非へム鉄周辺、そして $\mathrm{Mn}_{4} \mathrm{CaO}_{5}$ クラス夕 一周辺で有意な差が認められ、これらの領域で構造変化 が起きたことが示された ${ }^{51)}$ 。本稿では水分解反応に関連 して、 $\mathrm{Mn}_{4} \mathrm{CaO}_{5}$ クラスター周辺の構造変化についての み述べる。

Fig. 10A に示したように、2 閃光照射により OEC 周 辺で多くの差フーリエマップが見られ、多くの構造変化 が起きたことが示された。そのうち、Mn4 はキュバン の外側に若干 $(0.1-0.2 \AA)$ 移動し、Mn1 との距離が 少し長くなった。Ca, Mn1 についても一部の差フーリエ 密度が見られ、位置が変化したことが示唆された。しか し、水分解反応にとって重要な構造変化として以下の 3 つが見つかった。

O5 近傍にプラスの電子密度が見つかり、この部位に 新たな水分子（ヒドロキシル基あるいは酸素原子）が挿 入されたことが示唆された。

D1-Glu189 残基の側鎖が Mn1 側にフリップし、O5 と の間により大きなスペースを作った。

W665 という水分子に強いマイナスの電子密度が現 れ、この水分子が 2 閃光照射によってディスオーダーし たことが示された。

上記構造変化のうち、1)の構造変化により、O5 近 傍に新たな酸素原子 (水分子) O6が挿入されたことが 分かった (Fig. 10B)。O6はO5 と近い距離にあり、両 者の間で $\mathrm{O}=\mathrm{O}$ 結合を形成し、放出することが可能にな る ${ }^{51)}$ 。2)の構造変化は O6 の挿入を可能にするための もので、なぜなら、もしこの構造変化がなければ、D1Glu189のカルボキシル酸素のうちの一つは O6 と $2.3 \AA$ の距離にあり、O6の挿入が不可能になる。このため、 D1-Glu189 のカルボキシル基は $0.5 \AA$ ほど O5 から離れ る方向にシフトし (Fig. 11)、その結果、O6 との距離が $2.7 \AA$ になり、06の挿入が可能になる。

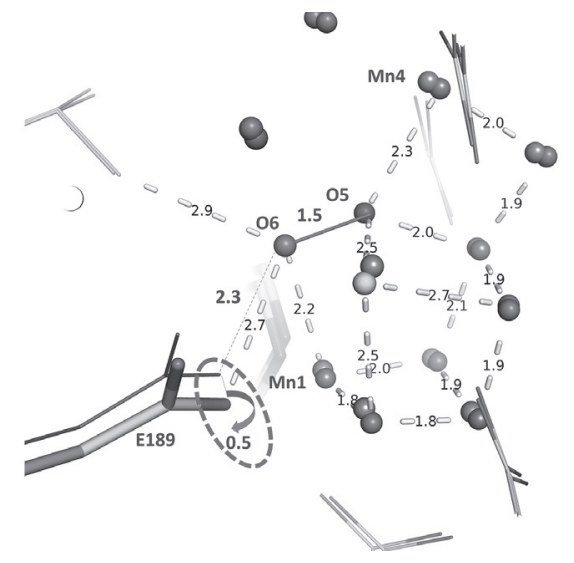

Fig. 11 Movement of the carboxylate group of D1-Glu189 induced by the 2-flashes illumination.

2 閃光照射によって引き起こされた構造変化のうち、 3)のW665 水分子のディスオーダーは、プロトンの排 出に関連していると考元られる。W665 はW567を介し て $\mathrm{Mn}_{4} \mathrm{CaO}_{5}$ クラスター中のオキソ酸素の一つ $\mathrm{O} 4$ と水 素結合によりつながっており、この水素結合は PSII 複 合体の表面、ルーメン側溶液まで他の水分子やアミノ酸 残基を介してネットワークを形成し、水分解反応に伴っ て放出されるプロトンがルーメン側溶液へ排出される経 路の一つとして考元られている ${ }^{52,53)}$ 。2 閃光照射するこ とによってW665 がディスオーダーすることにより、こ の水素結合ネットワークが切断されることになる。これ は、閃光照射により $\mathrm{Mn}_{4} \mathrm{CaO}_{5}$ クラスターから放出され たプロトンの一つがこのネットワークを通して外側（ル ーメン側）に排出され、排出されたプロトンの逆流を 防ぐため、水素結合ネットワークが一時的に切断され たことを反映していると考えられる。したがって、O4W567-W665 を介した水素結合ネットワークが、 $\mathrm{S}_{1} \rightarrow \mathrm{S}_{3}$ への遷移で放出されるプロトンの排出経路を担っている ことが示唆された ${ }^{51)}$ 。

\section{5. 水分解反応の機構}

$\mathrm{S}_{3}$ 状態における 06 の挿入により、 $\mathrm{O}=\mathrm{O}$ 分子の形成 部位や水分解反応の機構について重要な知見が得られ た。O6が O5 と極めて近いため、両者が反応基質であり、 分子状酸素を作り出していることが示された（Fig. 12）。 しかし、X 線構造解析での䛊差を考えれば、どのよう な機構で $\mathrm{O}=\mathrm{O}$ 結合が形成されるかについては不明な点 がある。筆者らが報告した構造では、O5 と O6 の距離

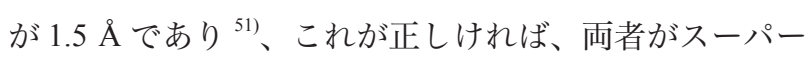
オキシド機構を通して $\mathrm{O}=\mathrm{O}$ 結合を形成することになる 48,54)。この場合、 $\mathrm{S}_{3}$ 状態で 2 つの $\mathrm{Mn}^{4+}$ が $\mathrm{Mn}^{3+}$ に還元さ れることが予想されるが、EPRやEXAFS の実験結果か ら $\mathrm{Mn}^{4+}$ の還元は観察されていない ${ }^{25,26,42)}$ 。構造解析の誤 差を考慮し、O5 - O6 の距離が $2.0 \AA$ 程度になれば、才 
キシルーオキソ (Oxyl-Oxo) 機構で $\mathrm{O}=\mathrm{O}$ 結合が形成さ れることになる。O5－O6 距離がさらに長く、2.4 $\mathrm{A}$ 程 度になれば、ヒドロキシルーオキソ (Hydroxyl-Oxo) 機 構になる ${ }^{48,54-56)}$ 。理論計算では後者の 2 つも可能であ ることが示されているが、どちらが正しいかは精度の高 い構造解析による検証が必要である。ここで触れておか なければならないのは、筆者らとほぼ同様のポンプ - プ ローブ法を用いて米国のグループが報告した $\mathrm{S}_{3}$ の構造 では、O6の挿入が観察されず、 $\mathrm{Mn}_{4} \mathrm{CaO}_{5}$ クラスターで 顕著な構造変化が見られず、別の反応機構が必要である ことが提案されていた ${ }^{57)}$ 。しかし、その実験から得られ たXFEL データの攵長度が低く、構造変化について結論 を導き出すには不十分と言わざるを得ない。実際、同著 者らはその後の追加実験により 06 に近い位置に新たな 水分子の挿入があることを示唆している。
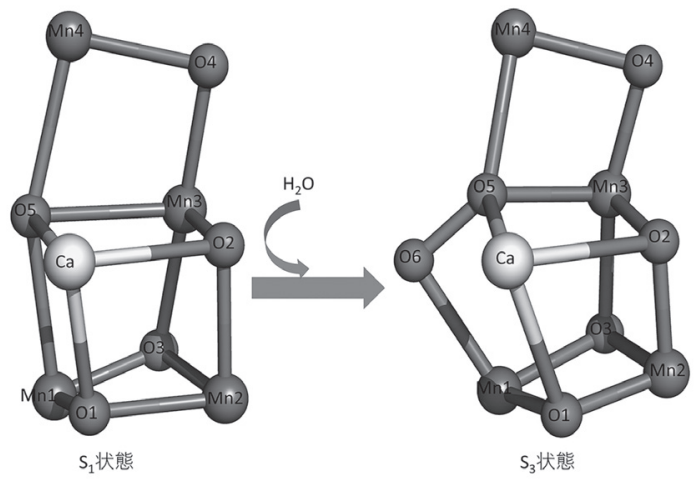

Fig. 12 Structure of the $\mathrm{Mn}_{4} \mathrm{CaO}_{5}$-cluster in the $\mathrm{S}_{1}$ and $\mathrm{S}_{3}$-states, showing the insertion of $\mathrm{O} 6$ and the structural changes of the cluster upon $\mathrm{S}_{1}$-to- $\mathrm{S}_{3}$ transition.

\section{6. プロトン排出チャンネル}

$\mathrm{Mn}_{4} \mathrm{CaO}_{5}$ クラスターは PSII 複合体の表面から中に入 った位置にあり、その周りは大きなタンパク質領域に覆 われており、外側の水溶液から隔離されている。これ は、水分子が $\mathrm{Mn}_{4} \mathrm{CaO}_{5}$ クラスターの基質でもあるため に、水との直接の接触を避けるために必要な配置である と思われる。もし、 $\mathrm{Mn}_{4} \mathrm{CaO}_{5}$ クラスターが直接水溶液に 露出し、自由に動き回っている水と接触していれば、ど の水分子を基質として使うか決められないかもしれな い。あるいは基質として結合している水分子がフリーの 水分子によって攻撃され、不安定化するかもしれない。 これは、触媒反応を秩序よく進めるために、ランダムな 基質ではなく、あらかじめ決まった位置に基質を配置し ておく必要性から取らなければならない戦略であったと 考えられる。実際、 $\mathrm{Mn}_{4} \mathrm{CaO}_{5}$ クラスターを覆つている夕 ンパク質（表在性タンパク質）の一部または全部を解離 させ、クラスターを覆っているキャップに穴を開けたり、 あるいはキャップを取り外したりすると、 $\mathrm{Mn}_{4} \mathrm{CaO}_{5}$ クラ スターが不安定になり、水分解活性の一部または全部が
失われることが知られており、これらタンパク質領域が $\mathrm{Mn}_{4} \mathrm{CaO}_{5}$ クラスターを水から隔離し、保護していること が示されている。 $\mathrm{Mn}_{4} \mathrm{CaO}_{5}$ クラスターが大きなタンパク 質領域に覆われていることは、別の問題をもたらす。す なわち、水分解に伴って 4 つのプロトンが放出されるが、 これらのプロトンを素早く反応部位から遠ざけ、複合体 の外側の溶液に排出する必要があるが、タンパク質中で のプロトンの自由拡散は速くないので、専用のプロトン 排出チャンネルが必要になる。高分解能結晶構造におい て、 $\mathrm{Mn}_{4} \mathrm{CaO}_{5}$ クラスターから複合体表面までつなぐ水素 結合ネットワークが複数見つかり、これらのネットワー クがプロトンチャンネルとして機能していることが示唆 された ${ }^{3,14,20)}$ 。そのうちの一つは上述した $\mathrm{O} 4$ を起点とす るネットワークで、2 閃光照射により W665 の構造変化 が確認され、 $\mathrm{S}_{1} \rightarrow \mathrm{S}_{3}$ 遷移に伴って放出されるプロトンの パスとして機能していることが示唆された。もう一つは $\mathrm{Y}_{\mathrm{Z}}$ (D1-Tyr161) とD1-His190 を介した水素結合ネット ワークで、赤外分光測定や D1-Gln298 の変異体を用いた 研究から、プロトンの排出に関わっていることが示唆さ れている ${ }^{58,59)}$ (Fig. 13)。この他にも、D1-Asp61を介し た水素結合ネットワークがプロトンの排出に重要な役割 を果たしていることが報告されている ${ }^{60,61)}$ 。

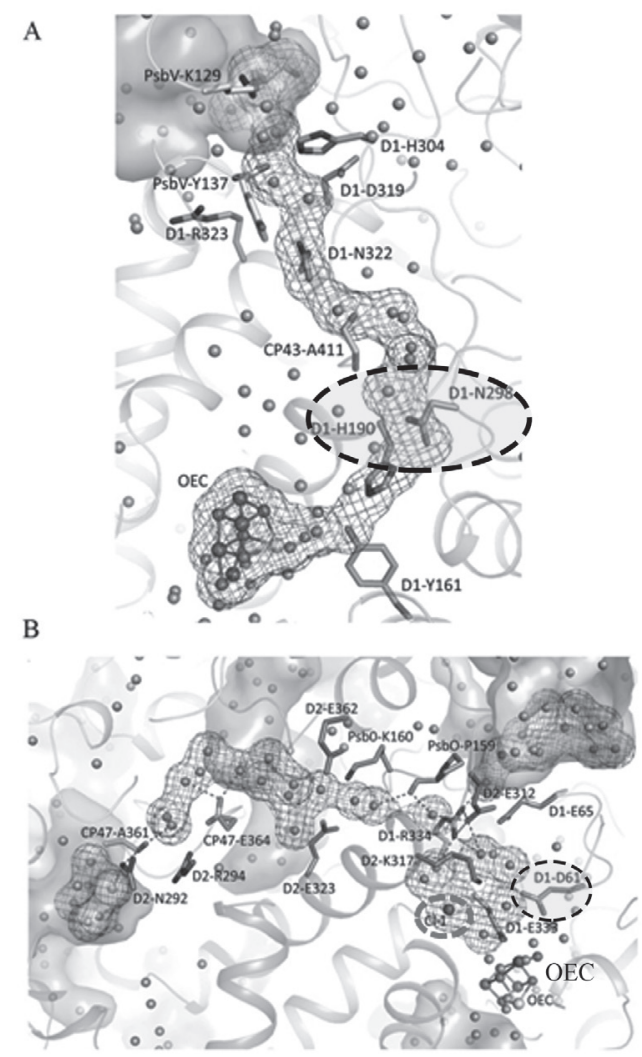

Fig. 13 Two hydrogen-bond networks starting from the OEC to outside of the PSII protein complex revealed by the high-resolution structural analysis. A. The hydrogen-bond network from OEC through His190-Asn298; B. The hydrogen-bond network from OEC through Asp61. 


\section{PSII における光捕集とエネルギー伝達}

$\mathrm{Mn}_{4} \mathrm{CaO}_{5}$ クラスターは水分解触媒として精密にでき ており、高い効率を有しているが、それを駆動している のはPSII の反応中心クロロフィルによって吸収された 光エネルギーである。しかし、光エネルギーが極めて希 薄なものであるため、一つのクロロフィルで吸収でき る光子は 1 秒間に 1 個強程度で ${ }^{62)}$ 、4 つの光子を吸収し て 2 分子の水を分解するためには、一つのクロロフィル が吸収した光のみで駆動するとなると、反応が極めて遅 くなる。この問題を解決するため、PSII は巨大な夕ン パク質複合体として進化させ、反応中心の周りに多くの クロロフィルを結合した「アンテナタンパク質」を配置 させた。これらアンテナタンパク質は、反応中心を結合 している D1, D2 タンパク質の両側に存在し、それぞれ CP47, CP43 と呼ばれるサブユニットである。この両サ ブユニットはそれぞれ 16 個、13 個のクロロフィルを結 合しており、吸収した光エネルギーを効率よく反応中心 に伝達するようになっている。
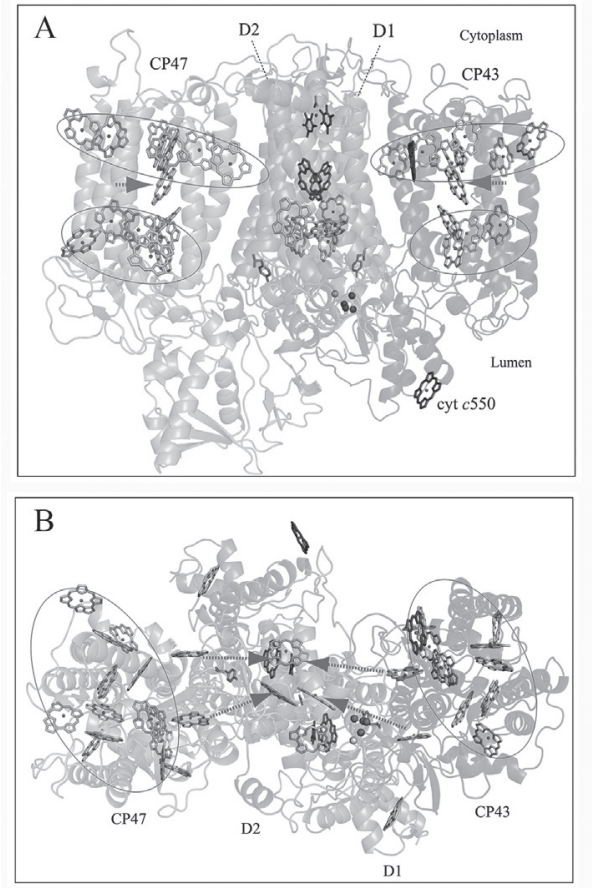

Fig. 14 Arrangement of the chlorophylls in the two antenna subunits CP47 and CP43, and their connections with the reaction center chlorophylls. A. Side view of the membrane, showing the distribution of chlorophylls in two layers; B. Connection of the bulk antenna chlorophylls with the reaction center chlorophylls through two "bridging" chlorophylls in each side.

CP47 と CP43 に結合しているアンテナクロロフィル は、主に膜の上（ストロマ側）と下（ルーメン側）の 二層に分布しており、各層内のクロロフィル同士は 10 ̊程度のセンター間距離にあり、効率よくエネルギーの 伝達・平衡化ができる構造になっている（Fig. 14A） ${ }^{14) 。 ~}$
また、2つの層の間では、1 個のクロロフィルが配置さ れており、層間のエネルギー伝達を仲介している。さら に CP47, CP43 と反応中心クロロフィルの間には各 $2 つ$ ずつのクロロフィルが配置されており、アンテナからの エネルギーを反応中心に「橋渡し」する役割を果たして いる (Fig. 14B) ${ }^{14)}$ 。ただし、これらの「橋渡し」クロ ロフィルと反応中心のクロロフィル間の距離（センタ ーとセンター）は $20 \AA$ 以上離れており、反応中心への エネルギー伝達の律速ステップになっている可能性があ る。反応中心からのこのような長い距離での橋渡しクロ ロフィルの配置は、反応中心からエネルギーの逆流を防 いでいると考えられており、長い進化の歴史で光合成生 物が見つけたエネルギー利用の最適化戦略であるといえ る。

\section{5. おわりに}

PSII の高分解能結晶構造、XFEL を利用した無損傷構 造や反応中間体の構造解析によって、可視光を利用した 水分解反応の機構について多くの重要な知見を得た。そ の結果、触媒としての $\mathrm{Mn}_{4} \mathrm{CaO}_{5}$ クラスターの詳細な構 造、 $\mathrm{O}=\mathrm{O}$ 結合の形成部位、プロトンの排出チャンネル などの多くが明らかになった。今後は残りの反応中間体 の構造、より早い時間での触媒の構造変化、各種変異体 の構造・機能解析などを通して、水分解の全貌やプロト ンパス、PSII の各サブユニットの詳細な役割などが解明 されるだろう。これらの知見は、水分解触媒の人工合成 にもヒントとなることが期待されるが、可視光を利用し た水分解の人工システムの創出には、光の吸収を水分解 の触媒にカップリングさせることも重要な課題となる。 生物は、長い進化の歴史を経て光吸収・電子伝達・水分 解をすべて同じタンパク質複合体内で完成させるように 変化してきたが、それぞれの過程を効率よくカップリン グさせることは容易ではない。人工システムでそれぞれ の要素技術の開発に合わせて、それらの間を効率よくつ なぐシステム工学的な手法が必要となる。地球大気中の 酸素がほとんど PSII から作られたものであり、生物の 生存に必要なエネルギーもほとんど PSII から始まる光 合成システムで太陽光から変換されたものであることを 考えると、生物進化の力の強大さを改めて感じざるを得 ない。

\section{6. 謝辞}

本稿で紹介した筆者らの研究は、多くの共同研究者と の共同研究の成果である。そのうち、放射光 X 線を利 用したPSII の高分解能構造解析は、神谷信夫教授、梅 名泰史博士（以上大阪市立大学）、川上恵典博士（当時： 
岡山大学)、XFEL を用いた無損傷構造解析は菅倫寬博 士、秋田総理博士、中島芳樹氏等 (以上岡山大学)、山 本雅貴博士、吾郷日出夫博士グループ (以上理化学研究 所）、 $\mathrm{S}_{3}$ 中間体の構造解析には菅倫寛博士、秋田総理博士、 中島芳樹氏等（以上岡山大学）、岩田想教授グループ (京 都大学)、菅原道泰博士、久保稔博士等 (以上理研) 等 の協力によるものである。この場を借りて感謝の意を表 します。

\section{7. 文献}

1) Photosystem II: The Light Driven Water: Plastoquinone Oxidoreductase, T. J. Wydrzynski, K. Satoh (eds), Springer, Dordrecht, The Netherlands (2005).

2) J.-R. Shen, T. Henmi, N. Kamiya, In Photosynthetic Protein Complexes, A Structural Approach, F. Fromme (ed), WILEY-VCH, pp. 83-106 (2008).

3) J.-R. Shen, Annu. Rev. Plant Biol., 66, 23 (2015).

4) B. Kok, B. Forbush, M. McGloin, Photochem. Photobiol., 11, 457 (1970).

5) P. Joliot, Photosynth. Res. 76, 65 (2003).

6) P. Joliot, G. Barbieri, R. Chabaud, Photochem. Photobiol., 10, 309 (1969).

7) I. Enami, A. Okumura, R. Nagao, M. Iwai, T. Suzuki, J.-R. Shen, Photosynth. Res., 98, 349 (2008).

8) T. M. Bricker, J. L. Roose, R. D. Fagerlund, L. K. Frankel, J. J. Eaton-Rye, Biochim. Biophys. Acta., 1817, 121 (2012).

9) K. Ifuku, Biosci. Biotechnol. Biochem., 79, 1223 (2015).

10) J.-R. Shen, M. Ikeuchi, Y. Inoue, FEBS Lett., 301, 145 (1992).

11) J.-R. Shen, Y. Inoue, Biochemistry, 32, 1825 (1993).

12) J.-R. Shen, N. Kamiya, Biochemistry, 39, 14739 (2000).

13) N. Kamiya, J.-R. Shen, Proc. Natl. Acad. Sci. U.S.A., 100, 98 (2003).

14) Y. Umena, K. Kawakami, J.-R. Shen, N. Kamiya, Nature, 473, 55 (2011)

15) B.A. Diner, F. Rappaport, Annu. Rev. Plant. Biol., 53, 551 (2002).

16) G. Raszewski, B.A. Diner, E. Schlodder, T. Renger, Biophys J., 95, 105 (2008).

17) K. Saito, T. Ishida, M. Sugiura, K. Kawakami, Y. Umena, N. Kamiya, J.-R. Shen, H. Ishikita, J. Am. Chem. Soc., 133, 14379 (2011).

18) K. Saito, J.-R. Shen, H. Ishikita, Biophys. J., 102, 2634 (2012).

19) A. Zouni, H. T. Witt, J. Kern, P. Fromme, N. Krauß, W. Saenger, P. Orth, Nature, 409, 739 (2001).

20) K. Kawakami, Y. Umena, N. Kamiya, J.-R. Shen, J. Photochem. Photobiol. B, 104, 9 (2011).

21) F. N. Ferreira, T.M. Iverson, K. Maghlaoui, J. Barber, S. Iwata, Science, 303, 1831 (2004).

22) B. Loll, J. Kern, W. Saenger, A. Zouni, J. Biesiadka, Nature, 438, 1040 (2005).

23) A. Guskov, J. Kern, A. Gabdulkhakov, M. Broser, A. Zouni, W. Saenger, Nat. Struct. Mol. Biol., 16, 334 (2009).

24）磯部＼cjkstart寛, Bull. Jpn. Soc. Coord. Chem., 70, 2 (2017).

25) C. Glöckner, J. Kern, M. Broser, A. Zouni, V. Yachandra, J. Yano, J. Biol. Chem., 288, 22607 (2013).

26) J. Yano, V. K. Yachandra, Chem. Rev., 114, 4175 (2014).

27) S. Luber, I. Rivalta, Y. Umena, K. Kawakami, J.-R. Shen, N.
Kamiya, G.W. Brudvig, V.S. Batista, Biochemistry, 50, 6308 (2011).

28) W. Ames, D.A. Pantazis, V. Krewald, N. Cox, J. Messinger, W. Lubitz, F. Neese, J. Am. Chem. Soc., 133, 19743 (2011).

29) K. Kanda, S. Yamanaka, T. Saito, Y. Umena, K. Kawakami, J.R. Shen, N. Kamiya, M. Okumura, H. Nakamura, K. Yamaguchi, Chem. Phys. Lett., 506, 98 (2011).

30) S. Yamanaka, H. Isobe, K. Kanda, T. Saito, Y. Umena, K. Kawakami, J.-R. Shen, N. Kamiya, M. Okumura, H. Nakamura, K. Yamaguchi, Chem. Phys. Lett., 511, 138 (2011).

31) T. Saito, M. Shoji, K. Kanda, H. Isobe, S. Yamanaka, Y. Kitagawa, S. Yamada, T. Kawakami, M. Okumura, K. Yamaguchi, Int. J. Quant. Chem., 112, 121 (2012).

32) A. Galstyan, A. Robertazzi, E.W. Knapp, J. Am. Chem. Soc., 134 7442 (2012).

33) R. Neutze, R. Wouts, D. van der Spoel, E. Weckert, J. Hajdu, Nature, 406, 752 (2000).

34) T. Ishikawa et al., Nat. Photon., 6, 540 (2012).

35) H.N. Chapman, C. Caleman, N. Timneanu, Philos. Trans. R. Soc. Lond. B. Biol. Sci., 369, 20130313 (2014).

36) S. Boutet, L. Lomb, G. J. Williams, T. R. Barends, A. Aquila, R. B. Doak, U. Weierstall, D. P. DePonte, J. Steinbrener, R. L. Shoeman, M. Messerschmidt, A. Barty, T. A. White, S. Kassemeyer, R. A. Kirian, M. M. Seibert, P. A. Montanez, C. Kenney, R. Herbst, P. Hart, J. Pines, G. Haller, S. M. Gruner, H. T. Philipp, M. W. Tate, M. Hromalik, L. J. Koerner, N. van Bakel, J. Morse, W. Ghonsalves, D. Arnlund, M. J. Bogan, C. Caleman, R. Fromme, C. Y. Hampton, M. S. Hunter, L. C. Johansson, G. Katona, C. Kupitz, M. Liang, A. V. Martin, K. Nass, L. Redecke, F. Stellato, N. Timneanu, D. Wang, N. A. Zatsepin, D. Schafer, J. Defever, R. Neutze, P. Fromme, J. C. Spence, H. N. Chapman, I. Schlichting, Science, 337, 362 (2012).

37) H. N. Chapman, Methods Mol. Biol., 1607, 295 (2017).

38) T. A. White, A. Barty, F. Stellato, J. M. Holton, R. A. Kirian, N. A. Zatsepin, H. N. Chapman, Acta Crystallogr. D. Biol. Crystallogr., 69, 1231 (2013).

39) M. Suga, F. Akita, K. Hirata, G. Ueno, H. Murakami, Y. Nakajima, T. Shimizu, K. Yamashita, M. Yamamoto, H. Ago, J.-R. Shen, Nature, 517, 99 (2015)

40) K. Hirata, K. Shinzawa-Itoh, N. Yano, S. Takemura, K. Kato, K. Muramoto, T. Kawahara, T. Tsukihara, E. Yamashita, K. Tono, G. Ueno, T. Hikima, H. Murakami, Y. Inubushi, M. Yabashi, T. Ishikawa, M. Yamamoto, T. Ogura, H. Sugimoto, J.-R. Shen, S Yoshikawa, H.Ago, Nature Methods, 11, 734 (2014).

41) A. Tanaka, Y. Fukushima, N. Kamiya, J. Am. Chem. Soc., 139, 1718 (2017)

42) N. Cox, M. Retegan, F. Neese, D. A. Pantazis, A. Boussac, W. Lubitz, Science, 345, 804 (2014).

43) D. R. Kolling, N. Cox, G. M. Ananyev, R. J. Pace, G. C. Dismukes, Biophys J., 103, 313 (2012).

44) R. J. Pace, L. Jin, R. Stranger, Dalton Trans., 41, 11145 (2012)

45) H. Isobe, M. Shoji, S. Yamanaka, Y. Umena, K. Kawakami, K. Kamiya, J.-R. Shen, K. Yamaguchi, Dalton Trans., 41, 13727 (2012).

46) D. A. Pantazis, W. Ames, N. Cox, W. Lubitz, F. Neese, Angew Chem. Int. Ed., 51, 9935 (2012).

47) M. Capone, D. Bovi, D. Narzi, L. Guidoni, Biochemistry, 54, 6439 (2015).

48) H. Isobe, M. Shoji, J.-R. Shen, K. Yamaguchi, Inorg. Chem., 55, 502 (2016). 
49) K. Yamaguchi, H. Isobe, M. Shoji, S. Yamanaka, M. Okumura, Mol. Phys., 114, 519 (2016).

50) D. Narzi, M. Capone, D. Bovi, L. Guidoni, Chemistry, 24, 10820 (2018).

51) M. Suga, F. Akita, M. Sugahara, M. Kubo, Y. Nakajima, T. Nakane, K. Yamashita, Y. Umena, M. Nakabayashi, T. Yamane, T. Nakano, M. Suzuki, T. Masuda, S. Inoue, T. Kimura, T. Nomura, S. Yonekura, L.-J. Yu, T. Sakamoto, T. Motomura, J.-H. Chen, Y. Kato, T. Noguchi, K. Tono, Y. Joti, T. Kameshima, T. Hatsui, E. Nango, R. Tanaka, H. Naitow, Y. Matsuura, A. Yamashita, M. Yamamoto, O. Nureki, M. Yabashi, T. Ishikawa, S. Iwata, J.-R. Shen, Nature, 543, 131 (2017).

52) K. Saito, A. W. Rutherford, H. Ishikita, Nat Commun., 6, 8488 (2015).

53) N. Sakashita, H.C. Watanabe, T. Ikeda, K. Saito, H. Ishikita, Biochemistry, 56, 3049 (2017).

54) M. Shoji, H. Isobe, T. Nakajima, Y. Shigeta, M. Suga, F. Akita, J.R. Shen, K. Yamaguchi, Faraday Discuss., 198, 83 (2017).

55) P. E. Siegbahn, J. Am. Chem. Soc., 135, 9442 (2013).

56) M. R. Blomberg, T. Borowski, F. Himo, R. Z. Liao, P. E. Siegbahn, Chem Rev. 114, 3601 (2014).

57) I. D. Young, M. Ibrahim, R. Chatterjee, S. Gul, F. D. Fuller, S. Koroidov, A. S. Brewster, R. Tran, R. Alonso-Mori, T. Kroll, T. Michels-Clark, H. Laksmono, R. G. Sierra, C. A. Stan, R. Hussein,
M. Zhang, L. Douthit, M. Kubin, C. de Lichtenberg, L. V. Pham, H. Nilsson, M. H. Cheah, D. Shevela, C. Saracini, M. A. Bean, I. Seuffert, D. Sokaras, T.-C. Weng, E. Pastor, C. Weninger, T. Fransson, L. Lassalle, P. Bräuer, P. Aller, P. T. Docker, B. Andi, A. M. Orville, J. M. Glownia, S. Nelson, M. Sikorski, D. Zhu, M. S. Hunter, T. J. Lane, A. Aquila, J. E. Koglin, J. Robinson, M. Liang, S. Boutet, A. Y. Lyubimov, M. Uervirojnangkoorn, N. W. Moriarty, D. Liebschner, P. V. Afonine, D. G. Waterman, G. Evans, P. Wernet, H. Dobbek, W. I. Weis, A. T. Brunger, P. H. Zwart, P. D. Adams, A. Zouni, J. Messinger, U. Bergmann, N. K. Sauter, J. Kern, V. K. Yachandra, J. Yano, Nature, 540, 453 (2016).

58) H. Kuroda, N. Kodama, X. Y. Sun, S. Ozawa, Y. Takahashi, Plant Cell Physiol., 55, 1266 (2014).

59) R. Nagao, H. Ueoka-Nakanishi, T. Noguchi, J. Biol. Chem., 292, 20046 (2017).

60) R. J. Service, W. Hillier, R. J. Debus, Biochemistry, 49, 6655 (2010).

61) R. J. Debus, Biochemistry, 53, 2941 (2014).

62) H. Inoue, T. Shimada, Y. Kou, Y. Nabetani, D. Masui, S. Takagi, H. Tachibana, ChemSusChem., 4, 173 (2011).

\section{Profile}

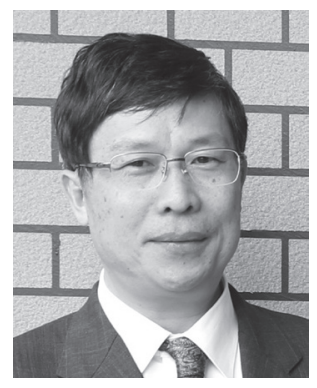

沈 建仁 (しん けんじん)

岡山大学異分野基礎科学研究所教授 理学博士

[経歴] 1986 年東京農工大学大学院農学研究科修士課程修了, 1990 年東京大学大学院理学研 究科博士課程修了, 同年理学博士取得。1990 年理化学研究所太陽光エネルギー研究グループ 基礎科学特別研究員, 研究員, 先任研究員を経て, 2003 年岡山大学大学院自然科学研究科教授, 2016 年より現職。朝日賞, みどりの学術賞, 日本結晶学会西川賞, 日本錯体化学会貢献賞等 を受賞

[専門] 光合成, 生化学, 植物生理学 